\title{
Echocardiographic features of eosinophilic endomyocardial disease
}

\author{
J DAVIES, D G GIBSON, R FOALE, K HEER, C J F SPRY, C M OAKLEY, J F GOODWIN \\ From Departments of Immunology and Medicine, Royal Postgraduate Medical School and Hammersmith Hospital, \\ London, and the Department of Cardiology, The Brompton Hospital, London
}

SUMMARY Nine patients with eosinophilic endomyocardial disease who had undergone angiocardiography with histological staging of their disease, were studied by $M$-mode and two dimensional $\stackrel{\omega}{\oplus}$ echocardiography to determine the extent to which specific features of the disease could be evaluated 9 by these non-invasive methods. In seven patients, amplitude processed two dimensional echo- $\vec{z}$ cardiography showed regions where the relative intensity of endomyocardial echoes was greater thano normal, and their distribution corresponded to known areas of fibrosis. Standard two dimensional $\stackrel{\oplus}{7}$ echocardiography was normal in all but three patients. In eight patients M-mode echocardiography showed only non-specific abnormalities, but appeared to be useful in assessing the functional conse- quences of myocardial or mitral valve disease. After digitisation a reduction in the duration and an $\vec{\oplus}$ increase in the peak rate of dimension increase during filling was found in four patients, while in two ${ }^{N}$ other patients the peak rate of dimension increase was reduced and filling was prolonged. It was. concluded that amplitude processed two dimensional echocardiography might be useful in diagnosing s the extent and severity of endomyocardial disease in patients with hypereosinophilia. These non-o invasive techniques may thus provide a means for the early diagnosis of endomyocardial fibrosis and could be useful in assessing its progression or response to treatment.

Eosinophilic endomyocardial disease became well known after Löffler's description of two patients in $1936,{ }^{1}$ and over 100 patients have now been described. It is characterised by a persisting blood eosinophilia and acute endocardial lesions which progress to endomyocardial fibrosis. This leads to a restrictive or obliterative cardiomyopathy, ${ }^{2}$ with impairment of diastolic filling. In addition, involvement of the papillary muscles can cause mitral and tricuspid regurgitation. In the majority of these patients the eosinophilia is idiopathic but in some an underlying cause such as a malignancy, allergic disease, or a hypersensitivity disorder can be defined.

Some studies of this condition using echocardiography have been reported, including Parrillo et al $^{3}$ who studied 18 patients with the hypereosinophilic syndrome and clinical features of endomyocardial disease, but on whom no invasive studies had been undertaken. Chew et al. ${ }^{4}$ described a pattern of restrictive ventricular filling in two patients with angiographically confirmed eosinophilic endomyocardial disease. Recently, five of 13 patients with the hyper-

Accepted for publication 15 April 1982 eosinophilic syndrome and suspected endomyocardial disease were found to have thickening of the posterior wall of the left ventricle in two dimensional echocardio- $\vec{\phi}$ grams. ${ }^{5}$ Though this report did not describe the angiographic or histological appearances in these patients, similar two dimensional echocardiographic abnor -3 malities were noted in a patient whose disease wasô confirmed at cardiac surgery. ${ }^{6}$

The present study was done to assess the value of echocardiography in patients with eosinophilic endo- $\rightarrow$ myocardial disease. In addition to standard $M$-mode and two dimensional techniques, recent methods forn digitisation of $M$-mode echocardiograms and colour coding of regional echo amplitude on two dimensionalo echocardiograms were also carried out. It was hoped that this would show whether echocardiography couldo detect endomyocardial disease in its early stages, ando whether it could be used to follow the evolution anco extent of the disease.

\section{Subjects and methods}

Nine patients with eosinophilic endomyocardia $\vec{b}$ disease were studied. They had undergone angio- 
Table 1 Summary of distribution of abnormalities in angiocardiograms, and histological staging of eosinophilic endomyocardial disease in nine patients

\begin{tabular}{|c|c|c|c|c|c|c|c|c|}
\hline \multirow[t]{2}{*}{ Case No. } & \multirow[t]{2}{*}{$\operatorname{Age}(y)$} & \multirow[t]{2}{*}{ Sex } & \multicolumn{3}{|c|}{$\begin{array}{l}\text { Duration of known heart disease } \\
\text { when study performed (years) }\end{array}$} & \multicolumn{2}{|c|}{$\begin{array}{l}\text { Distribution of cardiac abnormalities } \\
\text { in angiocardiograms }\end{array}$} & \multirow[t]{2}{*}{ Histological staging } \\
\hline & & & Angiogram & Histology & $\begin{array}{l}\text { Echo } \\
\text { study }\end{array}$ & Right side & Lefi side & \\
\hline$\frac{1}{2}$ & $\begin{array}{l}25 \\
49\end{array}$ & $\begin{array}{l}\mathbf{M} \\
\mathbf{M}\end{array}$ & $\begin{array}{l}0 \\
0\end{array}$ & $\begin{array}{l}0 \\
0\end{array}$ & $\begin{array}{l}0.8 \\
0.4\end{array}$ & $\begin{array}{l}\text { Normal } \\
\text { Apical obliteration }\end{array}$ & $\begin{array}{l}\text { Normal } \\
\text { Atrial enlargement; } \\
\text { apical irregularities }\end{array}$ & $\begin{array}{l}\text { Necrotic/thrombotic stage } \\
\text { Fibrotic stage }\end{array}$ \\
\hline 3 & 46 & $\mathbf{M}$ & 0.7 & 0.7 & $1 \cdot 2$ & $\begin{array}{l}\text { Atrial enlargement; } \\
\text { apical obliteration }\end{array}$ & $\begin{array}{l}\text { Atrial enlargement; } \\
\text { mitral regurgitation; } \\
\text { apical irregularities }\end{array}$ & Fibrotic stage \\
\hline 4 & 24 & $M$ & 0.6 & $0 \cdot 6$ & $1 \cdot 7$ & $\begin{array}{l}\text { Apical obliteration; } \\
\text { hyperdynamic in- } \\
\text { fundibulum }\end{array}$ & $\begin{array}{l}\text { Atrial enlargement; } \\
\text { mitral regurgitation; } \\
\text { apical irregularities }\end{array}$ & $\begin{array}{l}\text { Biopsy failed } \\
\text { (probable dense fibrosis) }\end{array}$ \\
\hline Postoperat & tive studies & M & 9.7 & 9.7 & 9.4 & $\begin{array}{l}\text { Atrial enlargement; } \\
\text { apical obliteration; } \\
\text { hyperdynamic in- } \\
\text { fundibulum }\end{array}$ & $\begin{array}{l}\text { Atrial enlargement; } \\
\text { mitral regurgitation; } \\
\text { apical obliteration }\end{array}$ & Fibrotic stage \\
\hline $\begin{array}{l}\text { Postoperat } \\
6\end{array}$ & $\begin{array}{l}\text { tove studie } \\
23\end{array}$ & F & 0.3 & $0 \cdot 3$ & 0.5 & Atrial enlargement; & Mitral regurgitation; & Thrombotic stage \\
\hline 7 & 25 & $\mathbf{M}$ & 0.7 & 0.5 & $2 \cdot 3$ & $\begin{array}{l}\text { apical irregularities } \\
\text { Atrial enlargement; } \\
\text { apical obliteration; } \\
\text { hyperdynamic in- } \\
\text { fundibulum }\end{array}$ & $\begin{array}{l}\text { apical irregularities } \\
\text { Atrial enlargement; } \\
\text { apical irregularities }\end{array}$ & Fibrotic stage \\
\hline 8 & 44 & $M$ & $6 \cdot 0$ & $4 \cdot 5$ & $6 \cdot 2$ & $\begin{array}{l}\text { Atrial enlargement; } \\
\text { apical obliteration } \\
\text { hyperdynamic in- } \\
\text { fundibulum }\end{array}$ & $\begin{array}{l}\text { Atrial enlargement; } \\
\text { apical irregularities }\end{array}$ & Fibrotic stage \\
\hline 9 & 52 & $\mathbf{M}$ & 0 & 0.1 & $8 \cdot 3$ & Apical obliteration & Apical irregularities & Fibrotic stage \\
\hline
\end{tabular}

cardiography, and a histological diagnosis had been obtained by cardiac biopsy or open heart surgery in eight. A biopsy attempt had failed in one patient, probably because of dense fibrosis preventing attachment of the biotome. Full clinical and cardiological features of these patients have been described separately. ${ }^{7}$ Table 1 summarises these findings and shows the stage in the disease when echocardiography was carried out. Two patients (cases 1 and 6) were studied during the early stages of the disease. The remainder had late fibrotic lesions at the time when echocardiography was carried out.

Four patients had previous cardiac surgery with replacement or repair of one or both atrioventricular valves. The mitral valve of case 6 had been replaced with a Carpentier-Edwards prosthesis and case 7 had been given a Starr-Edwards prosthesis. Case 8 had a right ventricular endocardectomy with mitral and tricuspid xenograft valve replacements and case 9 had a mitral valve repair.

\section{ECHOCARDIOGRAMS}

M-mode echocardiograms were performed on an echo IV machine (Electronics for Medicine) and recorded at a paper speed of $100 \mathrm{~mm} / \mathrm{s}$ on an instantaneous dry silver paper strip chart recorder. $2 \cdot 25 \mathrm{MHz}$ transducers were focused at $10 \mathrm{~cm}$. Patients were positioned in the left lateral decubitus position. Normal values were taken from previously published data. ${ }^{8}$ Echocardiograms were digitised as previously described ${ }^{10}$ using a
Summagraphics digitiser and a Prime $\mathbf{4 0 0}$ computer system. From these records, the following measurements were made.

(1) End-diastolic (synchronous with the $Q$ wave) and minimum left ventricular dimensions, from which fractional shortening was derived.

(2) Peak velocity of circumferential fibre shortening (normal range 2.0 to $3.0 \mathrm{~s}^{-1}$ ).

(3) Peak rate of dimension increase during filling (normal range 12 to $20 \mathrm{~cm} / \mathrm{s}$ ).

(4) Duration of rapid filling (normal $160-220 \mathrm{~ms}$ ). This period extends from the onset of the dimension increase at the start of diastole to the time when the first differential with respect to time falls below $20 \%$ of its peak value.

Two dimensional echocardiography was performed with a mechanical sector scanner (ATL Mark III) using a $3.5 \mathrm{MHz}$ transducer and $45 \mathrm{~dB}$ logarithmic grey scale compression. Standard views were used in all cases and the myocardium of the right ventricular inlet was imaged lateral to the tricuspid valve by slight angulation of the transducer from the standard parasternal minor axis view showing the aortic root and left atrium. Gain controls were set up for the parasternal view, and not altered thereafter during the examination. Swept gain was not used. All investigations were recorded on $3 / 4$ inch tape using a Sony U-matic videotape recorder (VO2631). An internally derived grey scale was superimposed on each display.

Colour image processing of two dimensional echo- 
(a)

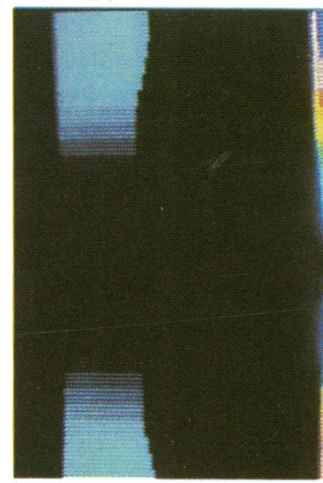

Fig. 1 (A) (b)
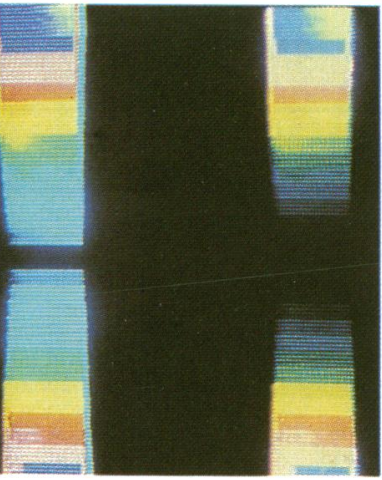

Fig. 2 (A)

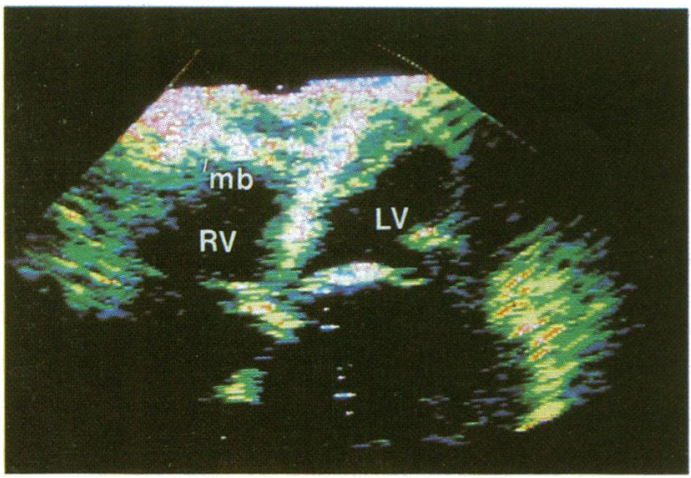

Fig. 3 (A)

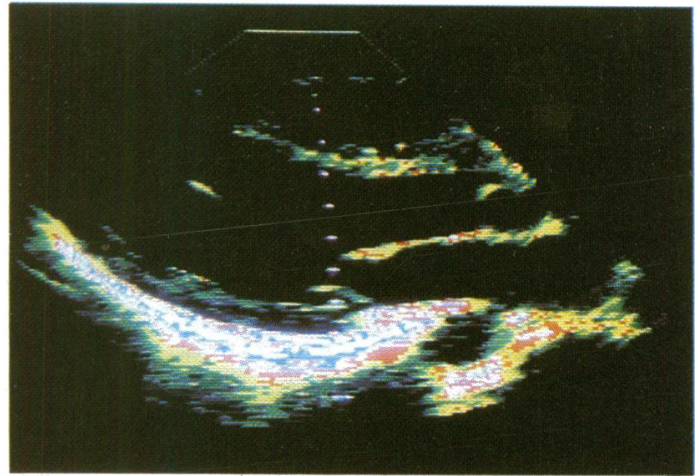

(B)

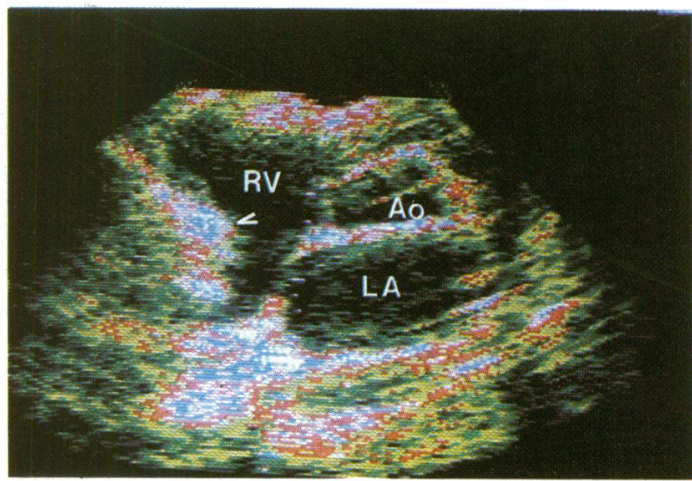

(B)

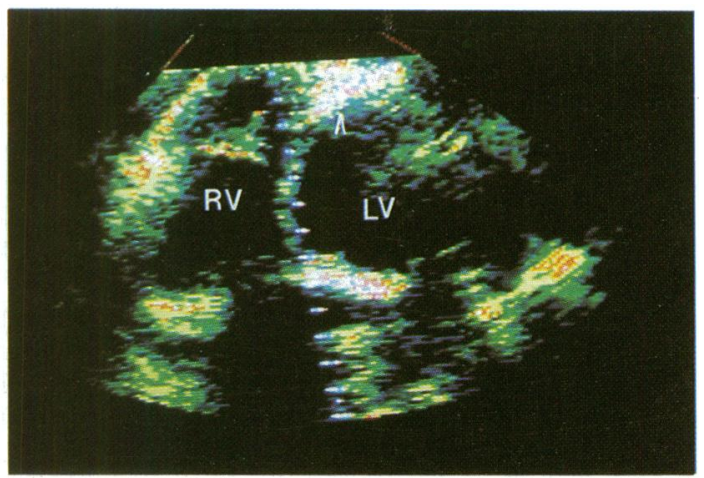

(B)

Fig. 1 (A) Comparison of three methods for displaying standard grey scale images. (a) Standard black and white image, (b) simple colour coded image, (c) processed image with modulation of both hue and luminosity. (B) Processed image, parasternal long axis view, of a normal heart.

Fig. 2 (A) Parasternal long axis view, processed image, showing echoes of increased amplitude returning from the posterior wall of the left ventricle and the attached papillary muscles $(p m)$, chordae, and anterior cusp. The arrow indicates thickening behind the posterior cusp. Note the layered appearances of the increased intensity echoes, with sparing of the medial side of the posterior wall of the left ventricle (case 1). (B) Parasternal minor axis view modified to show the right ventricular inflow tract. The arrow indicates increased intensity of reflected echoes from the lateral wall of the right atrium and the right ventricle (case 1 ).

Fig. 3 (A) Apical four chamber view, amplitude processed image, showing echoes of increased amplitude reflected from the apex of the right ventricle. They are also seen in the moderator band $(\mathrm{mb})$ of the right ventricle with echoes of normal amplitudes on either side (case 4). (B) Apical four chamber view, processed image, showing echoes of increased amplitude reflected from a well defined area at the base of the left ventricular septum. In addition, echoes with increased amplitude can be seen retuming from the septal cusp of the mitral valve (case 5). 
Table 2 Summary of $M$-mode echocardiograms in nine patients with eosinophilic endomyocardial disease

\begin{tabular}{|c|c|c|c|c|c|c|}
\hline Case No. & $\begin{array}{l}\text { Lefi atrial size at } \\
\text { end-systole }(\mathrm{cm})\end{array}$ & $\begin{array}{l}\text { Posterior wall } \\
\text { thickness, end- } \\
\text { diastole }(\mathrm{cm})\end{array}$ & Septal motion & $\begin{array}{l}\text { Septal thickness } \\
(\mathrm{cm})\end{array}$ & $\begin{array}{l}\text { Mitral valve } \\
\text { diastolic closure rate } \\
(\mathrm{cm} / \mathrm{s})\end{array}$ & Pericardial effusion \\
\hline $\begin{array}{l}1 \\
2 \\
3 \\
4 \\
5\end{array}$ & $\begin{array}{l}3 \cdot 9 \\
5 \cdot 1 \\
4 \cdot 5 \\
4.9 \\
5 \cdot 0\end{array}$ & $\begin{array}{l}1 \cdot 1 \\
1 \cdot 1 \\
1 \cdot 40 \\
0.70 \\
1 \cdot 30\end{array}$ & $\begin{array}{l}\text { Normal } \\
\text { Normal } \\
\text { Normal } \\
\text { Normal } \\
\text { Normal }\end{array}$ & $\begin{array}{l}0.8 \\
1.1 \\
1.0 \\
0.7 \\
0.8\end{array}$ & $\begin{array}{r}8 \\
4 \\
8 \\
25 \\
12\end{array}$ & $\begin{array}{l}\text { Small } \\
\text { Small } \\
\text { None } \\
\text { Small } \\
\text { Small }\end{array}$ \\
\hline $\begin{array}{l}\text { Postoperative studies } \\
6 \\
7 \\
8 \\
9 \\
\text { Normal range } \\
\text { Number abnormal }\end{array}$ & $\begin{array}{l}4 \cdot 1 \\
4 \cdot 3 \\
3.7 \\
3.5 \\
1.9-3.9 \\
6 / 9\end{array}$ & $\begin{array}{l}0.90 \\
0.80 \\
0.80 \\
1.40 \\
0.6-1 \cdot 1 \\
3 / 9\end{array}$ & $\begin{array}{l}\text { Normal } \\
\text { Normal } \\
\text { Reversed } \\
\text { Reversed } \\
\overline{2 / 9}\end{array}$ & $\begin{array}{l}0.9 \\
0.8 \\
0.8 \\
1.5 \\
0.6-1 \cdot 1 \\
1 / 9\end{array}$ & $\begin{array}{l}\text { Prosthesis } \\
\text { Prosthesis } \\
\text { Prosthesis } \\
\text { Valve repair } \\
5-15 \\
1 / 5\end{array}$ & $\begin{array}{l}\text { None } \\
\text { None } \\
\text { None } \\
\text { None } \\
\frac{1}{4 / 9}\end{array}$ \\
\hline
\end{tabular}

cardiograms was performed as previously described, ${ }^{11}$ using the Brompton Encoder (Alltek Hospital Supplies). Both black and white and processed views were analysed. The colour sequence, cyan, green, yellow, red, magenta, blue, and white (Fig. 1A), represented increasing relative echo amplitude. Zero amplitude was taken as black. The gain control of the encoder was adjusted to the minimum value at which the pericardium immediately beneath the left ventricular posterior wall appeared as a continuous white structure on the final display. Stop frame enddiastolic images were photographed and the dominant colour of individual structures was noted and expressed as a percentage, white being $100 \%$. A processed image, parasternal long axis view, of a normal heart is shown in Fig. 1B.

\section{Results}

\section{M-MODE ECHOCARDIOGRAMS}

A summary of the $M$-mode echocardiographic findings is shown in Table 2. Abnormalities were found in eight patients but these were minor in degree and none was specific for eosinophilic endomyocardial disease. In particular, posterior wall thickening could not be shown in four out of seven patients with known late fibrotic lesions. Most of the abnormalities found were compatible with mitral regurgitation, known to be present in some of the patients.

\section{DIGITISED RECORDS}

As shown in Table 3, peak velocity of circumferential fibre shortening and fractional shortening were reduced in only one patient. There was a wide range of values for the peak rate of filling and duration of rapid filling, with broadly two patterns of abnormal filling. Three patients (cases 4,7 , and 8 ) showed a decreased duration of rapid filling and two patients (cases 4 and 5 ) had an increased peak rate of filling-all of these patients had some degree of mitral regurgitation. Of the patients without mitral regurgitation, two (cases 1 and 9) had a normal filling pattern and two (cases 2 and 3) had a reduced peak rate and a prolonged duration of filling in the absence of haemodynamic obstruction to inflow.

\section{TWO DIMENSIONAL ECHOCARDIOGRAMS}

Grey scale display

The standard grey scale display showed an enlarged left atrium in six patients. In three, the posterior mitral valve leaflet appeared thickened and attached to a

Table 3 Summary of digitised M-mode echocardiograms in nine patients with eosinophilic endomyocardial disease

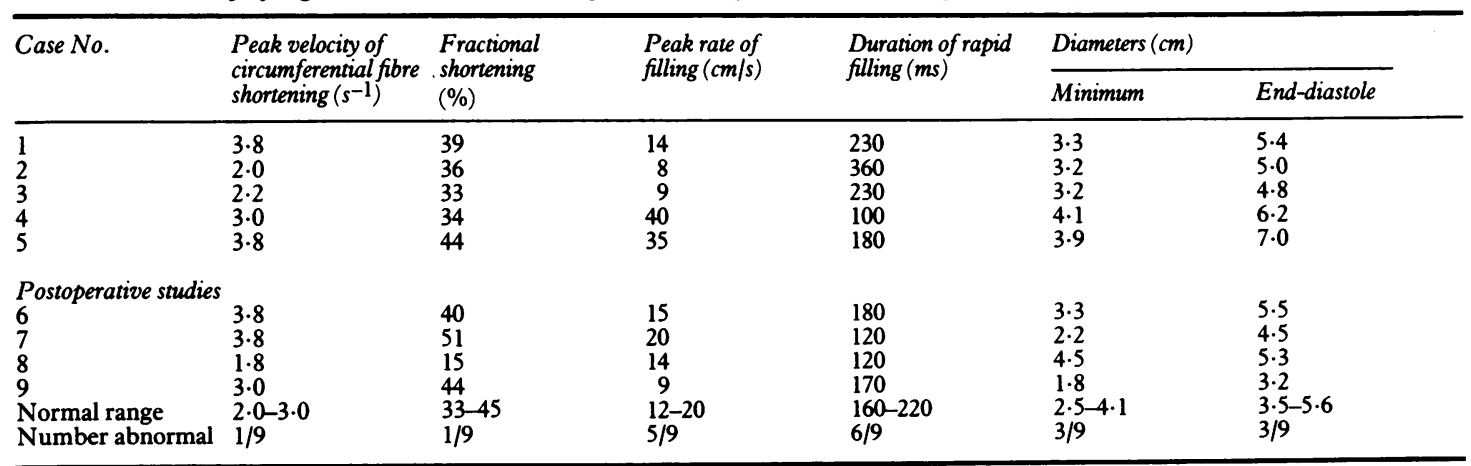


Table 4 Summary of amplitude processed two dimensional echocardiograms in nine patients with eosinophilic endomyocardial disease

\begin{tabular}{|c|c|c|c|c|c|c|c|c|}
\hline \multirow[t]{3}{*}{ Case No. } & \multicolumn{2}{|l|}{ Septum } & \multicolumn{6}{|c|}{ Amplitude of echoes expressed as percentage of pericardial echo value (100\%) } \\
\hline & \multirow[t]{2}{*}{ Apical } & \multirow[t]{2}{*}{ Basal } & \multirow{2}{*}{$\begin{array}{l}\text { Post. left } \\
\text { ventricular } \\
\text { wall }\end{array}$} & \multirow{2}{*}{$\begin{array}{l}\text { Papillary } \\
\text { muscles }\end{array}$} & \multicolumn{2}{|c|}{ Mitral cusps } & \multirow{2}{*}{$\begin{array}{l}\text { Right ventricle } \\
\text { apex }\end{array}$} & \multirow{2}{*}{$\begin{array}{l}\text { Other } \\
\text { sites }\end{array}$} \\
\hline & & & & & Anterior & Posterior & & \\
\hline $1^{\star}$ & 45 & 60 & 90 & 90 & 85 & 80 & 45 & $\begin{array}{l}\text { Right ventricle } \\
\text { inflow: } 90\end{array}$ \\
\hline $\begin{array}{l}2 \\
3 \\
\end{array}$ & $\begin{array}{l}35 \\
60\end{array}$ & $\begin{array}{l}35 \\
60\end{array}$ & $\begin{array}{l}60 \\
55\end{array}$ & $\begin{array}{l}35 \\
55\end{array}$ & $\begin{array}{l}60 \\
60\end{array}$ & $\begin{array}{l}60 \\
55\end{array}$ & $\begin{array}{l}55 \\
60\end{array}$ & - \\
\hline $4 \dagger$ & 80 & 60 & 60 & 45 & 80 & 80 & 60 & $\begin{array}{l}\text { Moderator band: } \\
90\end{array}$ \\
\hline Postoperative st & 90 & 80 & 60 & 80 & 90 & 90 & 70 & $\begin{array}{l}\text { Moderator band: } \\
85 \text {; right } \\
\text { ventricular } \\
\text { inflow } 90\end{array}$ \\
\hline $\begin{array}{l}\text { Postoperative st } \\
6\end{array}$ & 60 & 45 & 30 & Prosthesis & - & - & \multicolumn{2}{|c|}{ Postoperative study } \\
\hline 7 & 35 & 35 & 30 & Prosthesis & - & - & 30 & $\overline{-}$ \\
\hline $\begin{array}{l}8 \\
0\end{array}$ & 35 & 35 & 30 & Prosthesis & $\overline{60}$ & - & 35 & - \\
\hline 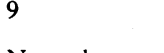 & 70 & 60 & 60 & $\begin{array}{l}\text { Mitral } \\
\text { valve repair }\end{array}$ & 60 & - & 90 & $\begin{array}{l}\text { Right ventricle } \\
\text { inflow: } 90\end{array}$ \\
\hline \multirow{2}{*}{$\begin{array}{l}\text { Normal range } \\
\text { Number } \\
\text { abnormal }\end{array}$} & $25-40$ & $25-40$ & $17-30$ & $30-40$ & $20-50$ & $20-50$ & $25-40$ & \\
\hline & $6 / 9$ & $6 / 9$ & $7 / 9$ & $4 / 5$ & $6 / 6$ & $5 / 5$ & $6 / 9$ & \\
\hline
\end{tabular}

^See Fig. 2.

†See Fig. 3A.

¥See Fig. 3B.

thickened left ventricular posterior wall (cases 4,5 , and 9). This endocardial thickening seemed to extend down into and to obliterate the ventricular apex in two of these patients. No abnormalities in the tricuspid valve, aortic root, aortic valve cusps, and anterior mitral leaflets were found. Systolic function was normal and no intracavity masses were seen.

\section{Colour coded images}

This technique showed a wide range of abnormalities in seven of the nine patients. These are summarised in Table 4 and echocardiograms from cases 1,4 , and 5 are shown in Fig. 2, 3A, and 3B, respectively. Increased amplitude echoes were seen most clearly in the inflow tracts of both left and right ventricles. This corresponded with areas of known fibrosis. High amplitude echoes were obtained from the left ventricle of case 1 who had been found to have a normal angiocardiogram 10 months earlier with a cardiac biopsy showing acute necrotic/thrombotic lesions. Though the method was reliable and apparently sensitive enough to detect early lesions in patients who had not been operated on, among the four patients who were studied postoperatively, two patients (cases 7 and 8 ) showed the least abnormal features. One of these patients (case 8) had had a right ventricular endocardectomy. The absence of high amplitude echoes from the left ventricle of these patients, however, remains unexplained. A striking feature in two patients was increased echo intensity from the region of the moderator band in the right ventricle (Fig. 3A). In one patient who had a history of cerebral emboli, a circular plaque of increased echo intensity was seen on the inferior surface of the septum near the left ventricular apex (Fig. 3B).

\section{Discussion}

Eosinophilic endomyocardial disease gives rise to a number of cardiological abnormalities which might be recognised echocardiographically. These include structural alterations such as endomyocardial fibrosis, cavity obliteration, or thrombi, and functional abnormalities directly resulting from myocardial involvement or secondary to atrioventricular valvular regurgitation. M-mode abnormalities reported by previous authors and confirmed in the present study were frequently the result of mitral regurgitation. These included disturbances of motion of the anterior mitral valve cusps and of ventricular wall motion during filling. M-mode echocardiography also identified small pericardial effusions in four patients and minor degrees of septal or posterior wall hypertrophy in three patients. Digitisation of M-mode echocardiograms gave little additional specific information. No evidence was seen of a "restrictive" pattern of wall motion, with curtailed early diastolic filling. The rate and extent of dimension changes were determined mainly by the presence or absence of mitral regurgitation, but two patients were noted to have a reduced rate of dimension increase and prolonged filling period similar to that seen in left ventricular hypertrophy. We were thus able to confirm earlier reports ${ }^{412}$ that $M$ mode echocardiography was not a reliable method for 
detecting the specific features of eosinophilic endomyocardial disease, though it was a useful technique for assessing abnormalities in left ventricular wall motion in these patients.

Two dimensional echocardiography, using a standard grey scale display, showed localised areas of echo-dense material on the posterior wall beneath the mitral valve in only three patients. Similar findings have been reported previously. ${ }^{5} 6$ When these patients were studied using the colour coded amplitude processed display, however, abnormally high intensity echoes were detected in seven patients. This localisation corresponded closely to known areas of fibrosis: the apex and inflow tracts of the right ventricle, and the apex and posterior wall of the left ventricle including the papillary muscles. Earlier experimental studies have already shown that collagen has a greater capacity than normal myocardium to reflect ultrasound in the frequency range which is used in echocardiography. ${ }^{13}$

As high intensity echoes arise from abnormal collagen deposits within the myocardium, it may be possible to demonstrate them by colour coded amplitude processed two dimensional echocardiography in other conditions in which fibrosis occurs, such as tropical endomyocardial fibrosis. In this disease M-mode echocardiography has shown non-specific features $^{14-16}$ which are similar to those seen in eosinophilic endomyocardial disease. Grey scale two dimensional echocardiography has also detected reduced contractility of left ventricular posterior wall, apical aneurysms, and adherence of the posterior cusp of the mitral valve to the posterior left ventricular wall. ${ }^{17}$ The distribution of localised areas of fibrosis which can occur in ischaemic heart disease has been described, ${ }^{11}$ and high intensity echoes from the septum and posterior wall have also been seen in patients with left ventricular hypertrophy, but their distribution is different and these are unlikely to be confused with the echocardiographic features of eosinophilic endomyocardial disease.

It is concluded that colour coded amplitude processed two dimensional echocardiography can provide valuable information about the extent and severity of eosinophilic endomyocardial disease. Endomyocardial abnormalities can be shown in the early and late stages of the disease when high intensity echoes are found which probably arise from abnormal collagen deposits. M-mode echocardiography, with and without digitisation, provides additional information about the effects of mitral valve involvement and left ventricular systolic and diastolic function. These appear to be valuable non-invasive techniques for diagnosing and studying the evolution of eosinophilic endomyocardial disease. They may be particularly useful for detecting early cardiac involvement in patients with hypereosinophilia and the early stages of tropical endo- myocardial fibrosis. Further work is needed, however, to see whether echocardiography can be used to follow the effects of treatment on the course of these diseases.

We thank colleagues for referring patients to our care: Professor D Julian, Dr A Holman, Dr E Besterman, Dr I Brooksby, and Dr P Hubner. We also thank Dr M Webb-Peploe for allowing us to study case 9 and Dr L Shapiro for his advice. Financial support by the Wellcome Trust and British Heart Foundation is acknowledged. The study was carried out under the auspicies of the International Society and Federation of Cardiology.

\section{References}

1 Löffler W. Endocarditis Parietalis Fibroplastica mit Bluteosinophilie. Schweiz Med Wochenschr 1936; 66: 817 20.

2 Olsen EGJ, Spry CJF. The pathogenesis of Löffler's endomyocardial disease and its relationship to endomyocardial fibrosis. Prog Cardiol 1979; 8: 281-303.

3 Parrillo JE, Borer JS, Henry WL, Wolff SM, Fauci AS. The cardiovascular manifestations of the hypereosinophilic syndrome. Am f Med 1979; 67: 572-82.

4 Chew CYC, Ziady GM, Raphael MJ, Nellen M, Oakley CM. Primary restrictive cardiomyopathy. Non-tropical endomyocardial fibrosis and hypereosinophilic heart disease. Br Heart f 1977; 39: 399-413.

5 Gottdiener JS, Schooley RT, Maron BJ, Fauci AS. Cardiac abnormality in the hypereosinophilic syndrome: identification of a unique mechanism for mitral regurgitation by two dimensional echocardiography (abstract). Circulation 1979; 60, suppl II: 19.

6 Weyman AE, Rankin R, King H. Löffler's endocarditis presenting as mitral and tricuspid stenosis. Am $\mathcal{F}$ Cardiol 1977; 40: 438-44.

7 Davies J, Spry CJF, Olsen EGJ, et al. Cardiovascular features of eleven patients with eosinophilic endomyocardial disease. 1981. Quart $\mathcal{F} \mathrm{Med}$ (in press).

8 Feigenbaum H. Echocardiography. 2nd ed. Philadelphia: Lea \& Febiger, 1976: 464.

9 Upton MT, Gibson DG. The study of left ventricular functions from digitized electrocardiograms. Prog Cardiovasc Dis 1978; 20: 359-84.

10 Gibson DG, Brown D. Measurement of instantaneous left ventricular dimension and filling rate in man, using echocardiography. Br Heart f 1973; 35: 1141-9.

11 Logan-Sinclair R, Wong CM, Gibson DG. Clinical application of amplitude processing of echocardiographic images. Br Heart f 1981; 45: 621-7.

12 Hess OM, Turina M, Senning A, Goebel NH, Scholer Y, Krayenbuehl HP. Pre- and postoperative findings in patients with endomyocardial fibrosis. Br Heart $\mathcal{F}$ 1978; 40: 406-15.

13 Chivers RC. Tissue characterisation. Ultrasound Med Biol 1981; 7: 1-20.

14 Pernod J, Gerbaux A, Vervin P, Terdjman M, Lelguem C, Droniou J. Apport de l'échocardiographie dans le diagnostic des fibroses endomyocardiques. Arch Mal Coeur 1980; 73: 139-46. 
15 Dienot B, Ekra A, Bertrand E. L'échocardiographic dans 23 cas de fibroses endomyocardiques constrictives droites ou bilatérales. Arch Mal Coeur 1979; 72: 1101-7.

16 Haertel JC, Castro I. Avaliação ecocardiográfica da fibrose endomiocárdica. Arq Bras Cardiol 1980; 35: 475-80.

17 Vijayaraghavan G, Sadanandan S. Left ventricular endomyocardial fibrosis (LVEMF), a two dimensional echocardiographic study (abstract). International conference on non-invasive techniques. p. 50. Bombay, December 1981. Proceedings of International Conference on Echocardiography.

Requests for reprints to Dr John Davies, Department of Immunology, Royal Postgraduate Medical School, 150 DuCane Road, London W12 0HS. 